\title{
Pengembangan Media Stimulasi Sensori Anak Usia 4- 6 Tahun Berbasis Aktivitas Bermain Tujuh Indera
}

\author{
Rosiyanah $^{\varpi_{1}}$, Yufiarti ${ }^{2}$, Sri Martini Meilani ${ }^{3}$ \\ Pendidikan Anak Usia Dini, Universitas Negeri Jakarta \\ DOI: $\underline{10.31004 / \text { obsesi.v5i1.758 }}$
}

\begin{abstract}
Abstrak
Keterbatasan pemberian stimulasi sensori pada tahun-tahun pertama kelahiran anak telah memunculkan berbagai perilaku anak dengan masalah sensori, sehingga menjadi kendala dalam beraktivitas sehari-hari saat anak memasuki dunia prasekolah. Berlatar kondisi itu maka penelitian ini bertujuan untuk menghasilkan produk media cetak berupa buku panduan aktivitas pembelajaran yang dapat menstimulasi kemampuan sensori anak usia 4-6 tahun dengan pendekatan bermain inderawi berbasis tujuh indera yang membantu guru dalam menstimulasi sensori anak. Metode penelitian menggunakan Research and Development (R\&D) dengan model pengembangan ADDIE yang terintegrasi dengan model Rowentree. Penelitian ini dilakukan pada 35 orang guru Taman Kanak-Kanak se Kecamatan Cempaka Putih, Jakarta Pusat. Berdasarkan hasil analisis data menunjukkan bahwa buku panduan yang dikembangkan memiliki kualitas yang sangat valid dan sangat layak untuk digunakan para guru dalam dalam memberikan stimulasi sensori yang terintegrasi dengan aktivitas pembelajaran yang tersusun secara terstruktur dan terkonsep, sehingga anak dapat berperilaku tepat terhadap sensasi yang muncul di lingkungan sekitar.

Kata Kunci: stimulasi sensori; aktivitas bermain; profil tujuh indera
\end{abstract}

\begin{abstract}
The limitations of providing sensory stimulation in the first years of childbirth have led to various behaviors of children with sensory problems, so that they become obstacles in their daily activities when children enter the world of preschool. With this background, this study aims to produce printed media products in the form of a learning activity guidebook that can stimulate the sensory abilities of children aged 4-6 years with a seven sensory based sensory play approach that helps teachers in stimulating children's sensory. The research method uses Research and Development (R\&D) with the ADDIE development model integrated with the Rowentree model. This research was conducted on 35 Kindergarten teachers in Cempaka Putih District, Central Jakarta. Based on the results of data analysis, it shows that the developed manual has a very valid quality and is very suitable for use by teachers in providing sensory stimulation that is integrated with learning activities that are structured and conceptualized, so that children can behave appropriately to the sensations that appear in the environment around.
\end{abstract}

Keywords: sensory stimulation; play activity; profile seven the senses.

Copyright (c) 2020 Rosiyanah, Yufiart2, Sri Martini Meilani

$\triangle$ Corresponding author :

Email Address : rosiyanah27@gmail.com ( Jakarta, Indonesia )

Received 10 September 2020, Accepted 16 September 2020, Published 17 September 2020 


\section{PENDAHULUAN}

Perkembangan anak usia dini menjadi dasar proses pembelajaran yang akan membentuk pengalaman dan menentukan perkembangan yang akan dibawa anak seumur hidup. Sebagai pondasi awal, masa usia dini menjadi penentu kesiapan dan keberhasilan anak dalam belajar pada pendidikan dimasa yang akan datang. Hal ini sejalan dengan pernyataan bahwa tahun-tahun pertama kehidupan anak, periode sejak janin dalam kandungan sampai anak berusia balita merupakan periode terpenting dan menjadi dasar perkembangan anak selanjutnya (Grantham-Mcgregor \& Smith, 2016). Hal ini juga diperkuat dengan pernyataan bahwa fase usia dini merupakan suatu fase dalam proses tumbuh kembang manusia yang mempengaruhi keberhasilan kehidupan sebagai individu dan memberikan kesempatan yang penting sebagai dasar bagi pembelajaran sepanjang hidup (Gladstone et al., 2018). Keberhasilan pada periode ini akan membantu anak untuk tumbuh dan berkembang secara optimal yang akan menjadi dasar pembelajaran anak sepanjang hidup. Sebagai upaya mengoptimalkan tumbuh kembang anak, maka selain nutrisi dan kasih sayang yang cukup, anak juga membutuhkan stimulasi yang tepat. Beberapa upaya stimulasi diberikan orangtua dan pengasuh hanya seputar satu aspek perkembangan tertentu saja. Sementara stimulasi pada perkembangan paling dasar menurut teori kognitif Piaget yaitu perkembangan sensori motor seringkali terabaikan saat anak berusia bayi 0-2 tahun. Padahal masa inilah seorang anak memiliki kepekaan dalam mempelajari sesuatu maka anak saat bayi membutuhkan stimulasi yang memperkaya pengalaman sensori motor, sehingga membantu bayi mengenal dunia dan dapat beraktivitas dalam kehidupan sehari-hari.

Hal ini diperkuat oleh Parham dan Mailloux yang menyatakan bahwa tahun-tahun pertama anak sebelum sekolah merupakan periode dalam perkembangan anak dimana integrasi sensorimotor berkembang pesat ketika anak berinteraksi dengan lingkungan (Zipp \& Olson, 2016). Sebuah tahap perkembangan, dimana anak membutuhkan stimulasi dalam bereksplorasi dengan mengembangkan tugas-tugas sensorik motorik sebagai cara belajar tentang diri mereka sendiri dan lingkungan mereka. Sensori merupakan sarana anak mengenal dan memahami dunia dan lingkungan sekitar anak. Pemrosesan sensori adalah proses menerima sensasi yang muncul di lingkungan terdekat lalu diorganisir, diolah kemudian ditafsirkan sensasi tersebut ke dalam sistem saraf pusat untuk menghasilkan reaksi yang tepat (Benson, Breisinger, \& Roach, 2019; Wan Yunus, Liu, Bissett, \& Penkala, 2015; Watts, Stagnitti, \& Brown, 2014). Proses ini merupakan proses dasar otak yang merasakan setiap input sensasi dari tubuh dan lingkungan sekitar yang kemudian diolah dan ditampilkan dalam bentuk perilaku-perilaku yang tepat. Setiap informasi sensasi yang ada di sekitar anak diharapkan dapat masuk dan diterima anak dan direspon dengan tepat melalui perilaku anak yang sesuai. Proses ini akan mempengaruhi kesiapan dan kemampuan anak dalam pembelajaran dan peran aktif anak pada aktivitas sehari-hari. Sehingga saat anak sudah memasuki dunia pra sekolah seharusnya semua anak bisa menjalani aktivitas sehari-hari sambil menjelajahi dan berinteraksi dalam lingkungan mereka dengan mudah.

Pada kenyataannya, terdapat beberapa anak mengalami kesulitan dalam beraktivitas sehari-hari disaat usia anak sudah melewati dua tahun. Dan tantangan yang saat ini terjadi justru pada anak yang sebetulnya normal dan sehat, namun kurang terstimulasi optimal, entah karena ketidak-tahuan atau keengganan orangtua atau pengasuh memberikan stimulasi sensori saat bayi. Padahal menurut penelitian menyatakan bahwa pengalaman sensoris mempengaruhi aktivitas anak-anak dalam rutinitas harian mereka tergantung dari sejauh mana pengalaman, makna dan perasaan yang diberikan oleh keluarga mereka sendiri (Critz, Blake, \& Nogueira, 2015). Seorang anak dapat berinteraksi dan berkomunikasi dengan lingkungan terdekat tergantung bagaimana pengalaman sensori yang diberikan keluarga sebagai pendidik pertama dan utama melalui kegiatan harian anak. Oleh karena itu penting sekali agar sensori anak distimulasi sedini mungkin sehingga mereka kelak dapat berkembang secara optimal. Minimnya stimulasi akan memunculkan penyimpangan pada tumbuh kembang anak bahkan gangguan yang menetap. Keterbatasan input sensori pada anak akan 
menjadi hambatan dan masalah sensoris pada masa tumbuh kembang yang seringkali ditunjukkan dengan gejala-gejala perilaku yang muncul dengan masalah sensori yang dikenal dengan perilaku disfungsi sensori (Chuang, Kuo, Fan, \& Hsu, 2017; Thompson \& Rains, 2009). Kondisi perilaku anak dengan masalah sensori ini seringkali menjadi hambatan dan gangguan dalam proses belajar anak saat anak memasuki dunia sekolah. Masalah sensori dapat dialami oleh siapa saja, bukan saja pada anak yang tergolong anak berkebutuhan khusus namun dapat dijumpai pada anak yang terlihat normal dikarenakan berkaitan dengan tumbuh kembang anak.

Kenyataan lain bahwa masalah sensori juga kurang dipahami guru ketika perilaku anak dengan masalah sensori muncul dalam pembelajaran, hal ini dikarenakan keterbatasan pengetahuan dan ketrampilan menstimulasi perkembangan sensori yang dimiliki beberapa guru anak usia dini. Penelitian menemukan bahwa rata-rata guru anak usia dini belum memiliki pengetahuan dan ketrampilan yang memadai untuk menstimulasi sensori anak, maka perlu diberikan pelatihan penggunaan media stimulasi pada guru (Yaswinda, Yulsyofriend, \& Mayar, 2018). Kondisi ini yang membuat aktivitas pembelajaran anak usia dini masih bersifat konvensional dengan media yang monoton dan kurang melibatkan sensori yang dimiliki anak-anak. Lingkungan belajar dan bermain juga kurang mendukung guru untuk memberikan intervensi dini dan stimulasi sensori pada anak yang memiliki perilaku dengan masalah sensori. Sehingga perilaku ini menjadi hambatan bahkan gangguan yang menetap dalam proses pembelajaran menjadi salah satu permasalahan guru yang membutuhkan penanganan khusus melalui kegiatan stimulasi sensori sedini mungkin. Pemberian stimulasi sensori sebaiknya diberikan melalui pendekatan bermain, mengingat dunia anak adalah bermain dan melalui bermain anak belajar. Bermain merupakan kegiatan yang melibatkan kemampuan dasar sensorik, motorik, kognitif, sosial komunikasi, dan interaksi fisik serta lingkungan sosial anak (Watts, Stagnitt, \& Brown, 2014). Bermain merupakan bagian dari dunia anak yang dapat mengembangkan potensi dan kemampuan dasar anak dalam masa tumbuh kembang. Namun era 4.0 saat ini cukup mempengaruhi permasalahan sensori pada anak, karena membuat sementara orangtua tergoda memberikan alat permainan games digital dan gadget yang membuat anak tenang, namun disisi lain membatasi kesempatan anak mengembangkan dan mengintegrasikan seluruh sensorinya secara seimbang. Perangkat elektronik telah menimbulkan fenomena bermain anak menjadi pasif sehingga informasi sensori dan stimulasi yang didapat anak menjadi terbatas yang akhirnya menjadi masalah sensori (Andriani, 2017). Berangkat dari keadaan tersebut itulah maka kecenderungan yang kemudian muncul adalah kebutuhan akan kegiatan bermain berbasis inderawi sebagai salah satu alternatif kegiatan bermain yang secara aktif melibatkan lebih dari satu indera sensori yang umumnya dikenal dengan kegiatan bermain indera atau Sensory Play.

Sensory play atau permainan inderawi dapat mengaktifkan sensori yang memiliki fungsi dalam meningkatkan pembelajaran, membangun ketrampilan kognitif dan menyelesaikan konflik sosial emosional anak (Welters-Davis \& Lawson, 2011). Pengalaman inderawi merupakan kegiatan yang mendorong anak menggunakan indera mereka untuk menjelajah dan menggali objek yang membangun pemahaman dan mendapatkan pengetahuan anak. Aktivitas inderawi merupakan suatu bentuk kegiatan dan bermain yang mendorong anak menggunakan satu atau lebih inderanya untuk menstimulasi sensori anak usia dini (Coulthard, Williamson, Palfreyman, \& Lyttle, 2018; Edwards, 2017; Watts, Stagnitti, et al., 2014). Penjelajahan anak dalam aktivitas inderawi itu sendiri akan menjadi landasan anak membangun diri untuk memahami dunianya sendiri. Permainan inderawi merupakan cara belajar anak yang melibatkan dan merangsang indera (Berkhout et al., 2012). Aktivitas inderawi selanjutnya memperluas persepsi anak terhadap dunia dengan pengalaman inderawi. Akhir dari aktivitas inderawi ini adalah mengasah persepsi inderawi dengan memberi kesempatan anak untuk merasakan pengalaman dan berkonsentrasi pada kualitas dan keseimbangan indera tertentu. Oleh karena itu anak-anak membutuhkan wilayah sensorik 
untuk memuaskan indera dan semua indera dalam mengeksplorasi suara, warna, cahaya, bau dan sentuhan. Sebuah tempat, dimana anak dapat menggunakan indera penglihatan, pendengaran, sentuhan, penciuman dan pengecapan untuk belajar sekaligus untuk membangun hubungan dalam proses tumbuh kembangnya. Melalui permainan indera dapat menstimulasi sensori yang menumbuhkan ekspresi kreatif dan membangun kepercayaan diri dan harga diri anak. Berbagai penelitian diatas memperlihatkan bahwa penelitian tentang kegiatan bermain sensori atau indera memberikan kontribusi yang cukup signifikan dalam menstimulasi berbagai aspek perkembangan pada setiap tahapan usia anak.

Kegiatan bermain indera dalam pemahaman umum hanya seputar panca indera, yang terdiri dari indera penglihatan, indera pendengaran, indera penciuman, indera pendengaran, indera penciuman, indera pengecapan dan indera perabaan. Tapi ternyata, indera yang dimiliki manusia itu ada tujuh, lima indera dengan rangsangan eksternal dan dua indera dengan rangsangan internal tubuh yaitu indera vestibular dan indera proprioseptif. Terintegrasi pemrosesan ketujuh indera ini yang tepat akan dapat mengoptimalkan pertumbuhan dan perkembangan anak selanjutnya. Dalam teori pemrosesan sensori integrasi pertama kali oleh Ayres, 1972 yang menyatakan bahwa setiap anak membutuhkan terintegrasinya stimulasi dari tujuh sensori, antara lain penglihatan, pendengaran, perabaan, penciuman dan perasa, vestibular, serta proprioceptif (Bagby, Dickie, \& Baranek, 2012). Keberadaan tujuh indera yang dimiliki akan membantu dan memudahkan anak beraktivitas harian secara mandiri. Hal ini diperkuat dengan hasil penelitian dari 155 anak-anak prasekolah menunjukan terdapat hubungan pola pemrosesan sensorik dari ketujuh indera dengan pola perilaku anak yang menjadi hambatan pembelajaran (Nesayan, Asadi Gandomani, Movallali, \& Dunn, 2018). Anak belajar melalui ketujuh indera yang terintegrasi dan saling bekerja sama, sehingga anak dapat dengan mudah melakukan aktivitas sehari-hari dalam proses pembelajaran. Sebaliknya, anak yang mengalami permasalahan dalam sensori secara umum akan mengalami kesulitan belajar kelak.

Kenyataan lain, kegiatan bermain indera hanya sekedar permainan yang hanya diterapkan dalam penanganan dini dalam proses terapi anak berkebutuhan khusus namun terintegrasinya kegiatan bermain sensori dengan proses pembelajaran anak usia dini secara umum masih terbatas dilakukan. Berdasarkan hasil observasi awal masih terdapat beberapa satuan pendidikan anak usia dini masih tampak melaksanakan pembelajaran yang belum melibatkan seluruh indera anak. Kecenderungan masih seputar indera penglihatan dan indera pendengaran yang dilibatkan anak, sementara lingkungan main dan pembiasaan aktivitas sehari-hari anak belum mengoptimalkan keterlibatan indera-indera lain yang melekat pada diri anak. Hal ini terjadi karena keterbatasan pengetahuan dan keterampilan guru terkait dengan perkembangan dan stimulasi sensori pada anak usia dini. Berdasarkan situasi tersebut diatas maka para pendidik anak usia dini perlu dibekali pengetahuan mengenai perkembangan sensori dan memiliki ketrampilan menstimulasi yang mudah dalam penerapan dalam aktivitas pembelajaran anak sehari-hari. Hal ini membuat kajian mengenai bagaimana menstimulasi perkembangan sensori pada anak usia dini melalui pendekatan kegiatan bermain yang melibatkan lebih dari satu indera bahkan tujuh indera layak diteliti. Sejalan dengan permasalahan di atas, maka tujuan dilakukan penelitian pengembangan ini adalah untuk mengembangkan sebuah produk buku panduan sebagai media stimulasi sensori pada anak usia 4-6 tahun dengan pendekatan aktivitas bermain tujuh indera yang diperuntukkan untuk para guru TK, sehingga dapat digunakan sebagai acuan untuk meningkatkan kompetensi pedagogis, sikap dan profesional terkait perkembangan sensori. Diharapkan para guru dapat menciptakan aktivitas bermain indera yang dapat menstimulasi sensori anak, sehingga anak dapat berperilaku adaptif dan merespon dengan tepat setiap sensasi yang ada di sekitar anak yang akan membangun kesiapan belajar anak secara akademik sebelum anak memasuki dunia sekolah dasar. 


\section{METODOLOGI}

Berdasarkan tujuan dari penelitian ini maka metode yang digunakan adalah metode R\&D (Research and Development) dengan menggunakan model pengembangan yang dipilih peneliti adalah model ADDIE yang terintegrasi dengan model Rowentree (Prawadilaga, 2015; Rowentree, 1994). Kedua model dipadukan sesuai dengan tujuan penelitian ini adalah mengembangkan media stimulasi sensori melalui buku panduan untuk guru anak usia dini. Adapun prosedur penelitian kedua model produk ini melalui tahapan sebagai berikut:

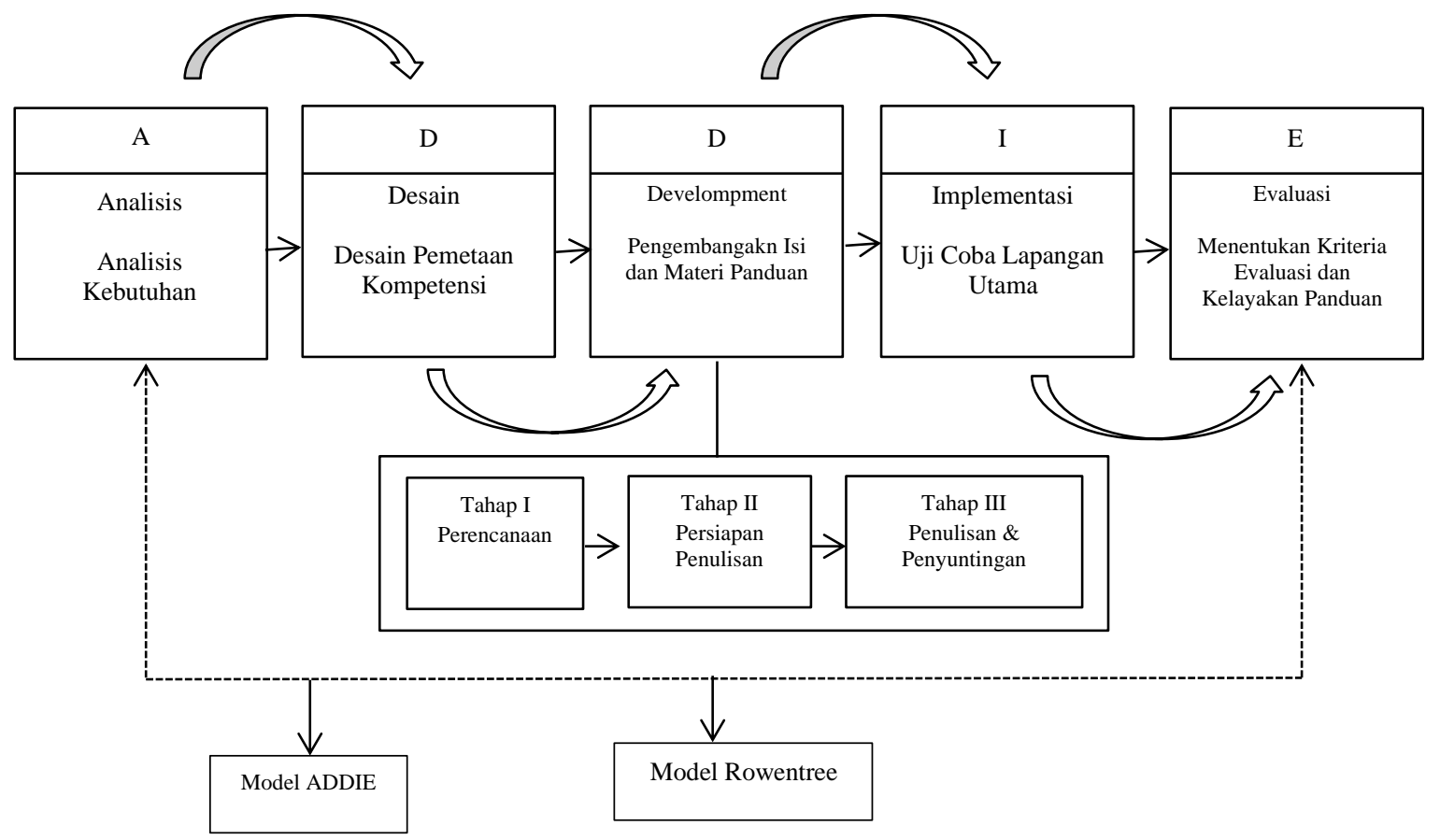

Gambar 1 Model Prosedural Penelitian

Tahap analisis yang dilakukan dengan mengidentifikasi beberapa hal yang terkait dengan keadaan yang nyata atau sesuai fakta yang muncul di lapangan (Setyosari, 2013). Berdasarkan hasil kuisioner singkat profil sensori anak yang dilakukan oleh para guru diketahui terdapat beberapa gejala perilaku anak di lembaga TK lingkungan kecamatan Cempaka Putih yang tertuang dalam grafik sebagai berikut:

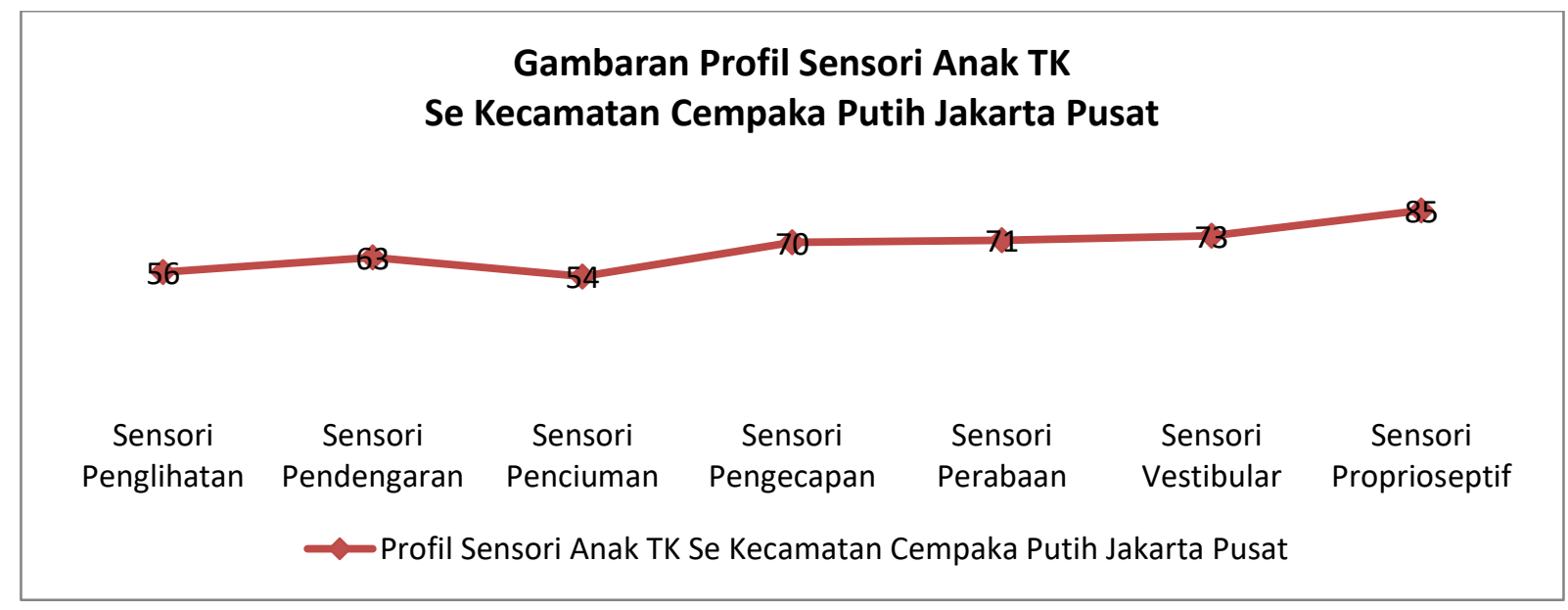

Grafik 1 Gambaran Profil Sensory 
Dari grafik 1 terdapat hasil profil sensori menggambarkan bahwa perilaku anak dengan masalah sensori dapat dialami pada anak-anak yang terlihat normal atau tanpa kebutuhan khusus muncul dalam aktivitas sehari-hari anak di satuan pendidikan Taman Kanak-Kanak lingkungan Kecamatan Cempaka Putih. Gambaran profil sensori merupakan ketidakmampuan anak memproses informasi sensori setiap sensasi yang muncul di sekitar akan memberikan pengaruh anak dalam berkonsentrasi dan menjaga fokus anak saat dalam proses pembelajaran (Dunn, 1999; Yudhiatmoko, 2014). Gejala perilaku anak ini kemungkinan dapat dikatakan menjadi hambatan dalam kemandirian dan kesiapan anak belajar saat anak memasuki dunia pra sekolah apabila tidak terstimulasi dengan tepat.

Analisis kebutuhan berdasarkan responden survei adalah sebanyak 108 guru Taman Kanak-Kanak yang ada di Kecamatan Cempaka Putih Jakarta Pusat Provinsi DKI Jakarta didapat data dalam grafik sebagai berikut:

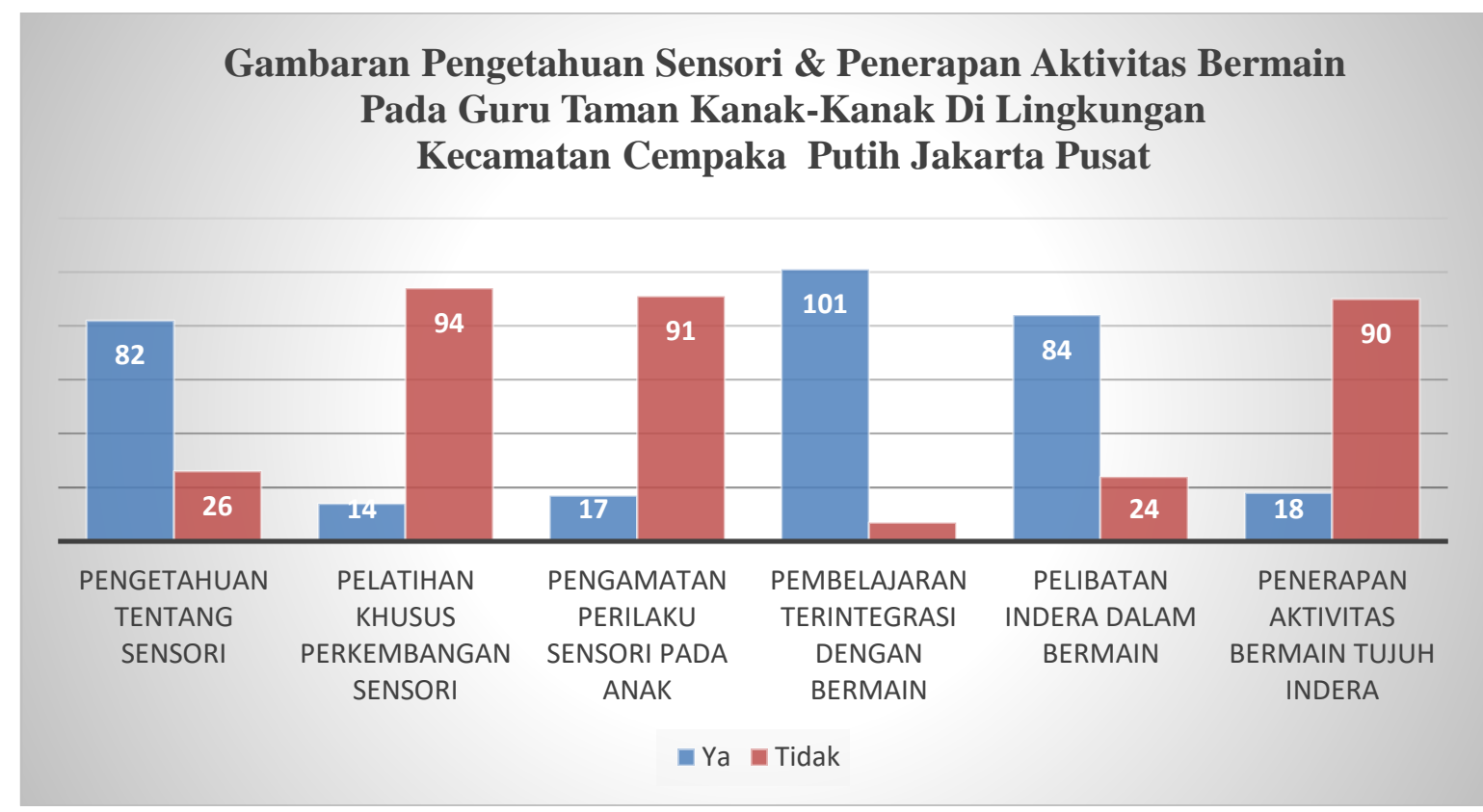

\section{Grafik 2 Gambaran Pengetahuan Sensori Guru dan Penerapan Aktivitas Bermain}

Dari grafik 2 di gambarkan bahwa para guru memiliki pengetahuan terkait sensori masih bersifat umum, sedangkan pemahaman secara mendalam belum dimiliki karena sekitar $13,88 \%$ guru menyatakan yang sudah pernah mengikuti pendidikan dan pelatihan terkait dengan perkembangan sensori. Kenyataan lain ditemukan sekitar 93,51\% guru sudah menerapkan pendekatan bermain dalam pembelajaran maupun aktivitas sehari-hari anak, namun sekitar 77,77 \% guru sudah melibatkan indera anak secara aktif. Namun dari pertanyaaan yang diajukan terdapat jawaban beberapa guru yang menyatakan bahwa pelibatan indera dalam aktivitas anak baru sebatas panca atau lima indera bahkan cenderung hanya indera penglihatan dan pendengaran saja. Dari hasil analisis terdapat sekitar 83,33\% guru yang menyatakan belum pernah mengenal istilah dan informasi terkait dengan tujuh indera, sehingga hal ini membuat sebagian guru belum sepenuhnya menerapkan pembelajaran dan aktivitas bermain dengan melibatkan seluruh indera secara aktif.

Pada tahap desain ini peneliti merancang tujuan dengan cara menjabarkan tujuan umum ke dalam tujuan yang lebih spesifik (Setyosari, 2013). Setelah proses analisis kebutuhan dan kinerja dalam pengembangan buku panduan selesai peneliti laksanakan maka selanjutnya peneliti menentukan peta kebutuhan buku panduan sesuai dengan kompetensi guru yang akan dicapai yang disusun dan tergambarkan dalam dua bentuk garis besar yaitu desain pemetaan kompetensi dan desain materi panduan yang sesuai dengan kompetensi yang hendak dicapai menjadi garis besar dalam pengembangan produk buku panduan. 
Tabel 1. Desain Pemetaan Kompetensi dan Materi Panduan Stimulasi

\begin{tabular}{|c|c|c|c|}
\hline No & Tujuan & Kompetensi & Materi Panduan \\
\hline 1 & $\begin{array}{l}\text { Pedagogis } \\
\text { Memahami karakteristik } \\
\text { perilaku anak dengan } \\
\text { masalah sensori }\end{array}$ & $\begin{array}{l}\text { Memahami karakteristik dan } \\
\text { tugas perkembangan anak serta } \\
\text { memiliki pengetahuan tentang } \\
\text { perkembangan dan } \\
\text { karakteristik profil sensori } \\
\text { anak. }\end{array}$ & $\begin{array}{l}\text { Pemahaman dari sistem } \\
\text { sensori,peran penting } \\
\text { perkembangan sensori. } \\
\text { Karakteristik perilaku anak } \\
\text { dengan masalah sensori. } \\
\text { Prinsip stimulasi sensori. }\end{array}$ \\
\hline 2 & $\begin{array}{l}\text { Sikap } \\
\text { Menunjukkan sikap dan } \\
\text { tanggung jawab yang tinggi } \\
\text { terkait } \\
\text { menstimulasiperkembangan } \\
\text { sensori anak. }\end{array}$ & $\begin{array}{l}\text { Menunjukkan etos kerja dan } \\
\text { tanggung jawab yang tinggi } \\
\text { dengan mendukung kegiatan } \\
\text { stimulasi dini sensori dengan } \\
\text { pendekatan aktivitas bermain. }\end{array}$ & $\begin{array}{l}\text { Prinsip dan petunjuk } \\
\text { penerapan pelaksanaan } \\
\text { stimulasi sensori yang } \\
\text { dapat terintegrasi dengan } \\
\text { pembelajaran dalam satuan } \\
\text { pendidikan. }\end{array}$ \\
\hline 3 & $\begin{array}{l}\text { Profesional } \\
\text { Menunjukkan } \\
\text { profesionalisme dalam } \\
\text { menyusun perencanaan, } \\
\text { pelaksanaan, penilaian } \\
\text { pembelajaran anak. }\end{array}$ & $\begin{array}{l}\text { Mampu memantau dan } \\
\text { memberikan rangsangan sesuai } \\
\text { dengan tahap perkembangan } \\
\text { anak serta mampu menerapkan } \\
\text { ide kreasi aktivitas bermain } \\
\text { yang dapat menstimulasi } \\
\text { sensori anak dalam } \\
\text { pembelajaran. }\end{array}$ & $\begin{array}{l}\text { Aktivitas bermain tujuh } \\
\text { indera, teknik pelaksanaan } \\
\text { tahapan skenario bermain } \\
\text { tujuh indera, tips memulai } \\
\text { aktivitas bermain tujuh } \\
\text { indera, pengembangan } \\
\text { tema aktivitas bermain } \\
\text { tujuh indera }\end{array}$ \\
\hline
\end{tabular}

Tabel 1 merupakan draft desain kompetensi guru yang akan dicapai sebagai suatu blue print (Pribadi, 2015) yaitu rencana keseluruhan garis besar isi sebuah panduan yang bertujuan meningkatkan kompetensi guru baik pedagogis, sikap dan profesional terkait dengan perkembangan sensori anak usia dini. Draft ini akan menjadi acuan peneliti dalam mengembangkan isi dan materi yang dapat memenuhi kompetensi guru dalam sebuah buku panduan.

Dalam tahap pengembangan (development) ini peneliti melakukan dua langkah yaitu 1) pengembangan bahan dan materi panduan terbaik yang akan digunakan untuk mencapai tujuan kompetensi, 2) memproduksi bahan ajar yang akan digunakan untuk mencapai tujuan pembelajaran yang telah dirumuskan dalam tahap desain sebelumnya (Pribadi, 2015).

Tabel 2. Pengembangan Materi Panduan Stimulasi Sensori

\begin{tabular}{ccl}
\hline No & $\begin{array}{c}\text { Bagian } \\
\text { Buku }\end{array}$ & \\
\hline 1 & $\begin{array}{c}\text { Bagian } \\
\text { Pertama }\end{array}$ & Stimulasi Dini \\
\cline { 3 - 3 } & & Pengertian sensori dan peran penting dalam perkembangan. \\
\cline { 3 - 3 } & Bagian & Profil Sensori \\
\cline { 3 - 3 } & Kedua & Pembelajajaran berbasis sensori \\
\cline { 3 - 3 } & Bagian & Prinsip Pembelajaran Sesori \\
\cline { 3 - 3 } & Ketiga & Penerapan Pembelajaran Berbasis Sensori \\
\cline { 3 - 3 } & & Profil Tujuh Indera \\
\cline { 3 - 3 } & Bagian & Aktivitas Bermain Tujuh Indera \\
\cline { 3 - 3 } & Keempat & Panfaat Aktivitas Bermain Tujuh Indera \\
\cline { 3 - 3 } & & Pahapanan Skenario Bermain Tujuh Indera \\
\cline { 3 - 3 } & & Pengembangan Tema Aktivitas Bermain \\
\cline { 3 - 3 } & & Bentuk Aktivitas Bermain Tujuh Indera \\
\cline { 3 - 3 } & & Asesmen Perkembangan Anak \\
\hline
\end{tabular}


Tabel 2 menggambarkan suatu ide dan rancangan materi sebuah buku panduan yang menjadi acuan para guru untuk meningkatkan kompetensi terkait dengan perkembangan dan stimulasi sensori yang tertuang dalam bentuk disain garis besar materi panduan stimulasi sensori.

Pada langkah kedua dari tahap pengembangan model ADDIE yaitu memproduksi bahan ajar berbasis cetak yaitu media panduan stimulasi sensori berbasis aktivitas bermain tujuh indera, peneliti mengintegrasikan tahapan pengembangan ini dengan model Rowentree yang bertujuan memproduksi bahan ajar berbasis cetak dengan tepat melalui langkah-langkah sebagai berikut: 1) Kegiatan pada tahap perencanaan ini peneliti mengidentifikasi profil guru sebagai pengguna produk buku panduan adalah para guru TK yang terdaftar dalam satuan pelaksana pendidik Kecamatan Cempaka Putih Jakarta Pusat, setelah melakukan analisis peneliti menemukan beberapa perilaku anak dengan masalah sensori yang menjadi hambatan dalam proses pembelajaran, namun tidak diimbangi dengan pengetahuan dan ketrampilan penanganan dini yang memadai. Materi pendukung panduan sebagai pertimbangan menentukan karakteristik media yang akan dikembangkan sebagai media stimulasi sensori dengan pendekatan aktivitas bermain tujuh indera yang dikemas dengan media buku panduan yang praktis dan mudah menggunakan kapan dan dimana saja. 2) Kegiatan persiapan penulisan ini dengan mengurutkan ide atau gagasan materi dalam mengembangkan struktur penulisan buku panduan, mengembangkan aktivitas bermain tujuh indera, menentukan contoh terkait materi, menentukan grafis atau ilustrasi gambar pendukung materi, merumuskan bentuk fisik buku panduan stimulasi dini sensori ini.

Tabel 3. Pengembangan Struktur Penulisan Isi Panduan

\begin{tabular}{|c|c|c|}
\hline $\begin{array}{c}\text { Struktur } \\
\text { Buku }\end{array}$ & $\begin{array}{l}\text { Bagian } \\
\text { Buku }\end{array}$ & Bahan dan Materi \\
\hline Sampul & $\begin{array}{l}\text { Sampul } \\
\text { Depan }\end{array}$ & $\begin{array}{l}\text { Judul "Panduan stimulasi sensori anak usia } 4-6 \text { tahun berbasis } \\
\text { aktivitas bermain tujuh indera". }\end{array}$ \\
\hline \multirow[t]{2}{*}{$\begin{array}{l}\text { Lembaran } \\
\text { Awal }\end{array}$} & $\begin{array}{c}\text { Kata } \\
\text { Pengantar }\end{array}$ & Untaian Pra Kata Penulis \\
\hline & Daftar Isi & Sub judul dan sub bahasan materi panduan \\
\hline \multirow{4}{*}{$\begin{array}{l}\text { Sub Judul } \\
\text { Satu }\end{array}$} & \multirow[t]{4}{*}{ Pendahuluan } & Mengapa panduan ini ada?? \\
\hline & & Petunjuk penggunaan panduan \\
\hline & & Sasaran dan tujuan \\
\hline & & Lembar evaluasi diri awal \\
\hline \multirow{6}{*}{$\begin{array}{l}\text { Sub Judul } \\
\text { Dua }\end{array}$} & \multirow{6}{*}{$\begin{array}{l}\text { Stimulasi } \\
\text { Sensori }\end{array}$} & Stimulasi tumbuh kembang \\
\hline & & Apa itu sensori?? \\
\hline & & Sistem sensori integrasi \\
\hline & & Peran penting sensori dalam perkembangan anak \\
\hline & & Perilaku anak dengan masalah sensori \\
\hline & & Prinsip stimulasi sensori \\
\hline \multirow{4}{*}{$\begin{array}{l}\text { Sub Judul } \\
\text { Tiga }\end{array}$} & \multirow{4}{*}{$\begin{array}{c}\text { Penerapan } \\
\text { pembelajaran } \\
\text { Berbasis } \\
\text { Stimulasi } \\
\text { Sensori }\end{array}$} & Prinsip penerapan pembelajaran berbasis stimulasi sensori \\
\hline & & Petunjuk pelaksanaan pembelajaran berbasis stimulasi sensori \\
\hline & & Kuesioner profil sensori \\
\hline & & Pengembangan indikator pencapaian kemampuan sensori \\
\hline \multirow{5}{*}{$\begin{array}{l}\text { Sub Judul } \\
\text { Empat }\end{array}$} & \multirow{5}{*}{$\begin{array}{c}\text { Aktivitas } \\
\text { Bermain } \\
\text { Tujuh } \\
\text { Indera }\end{array}$} & Apa itu tujuh indera?? \\
\hline & & Profil Tujuh Indera \\
\hline & & Mengapa tujuh indera?? \\
\hline & & Apa itu aktivitas bermain indera?? \\
\hline & & Manfaat Aktivitas bermain tujuh indera \\
\hline \multirow{4}{*}{$\begin{array}{l}\text { Sub Judul } \\
\text { Lima }\end{array}$} & \multirow{4}{*}{$\begin{array}{l}\text { Pelaksanaan } \\
\text { aktivitas } \\
\text { bermain tujuh } \\
\text { indera }\end{array}$} & Tahapan aplikasi aktivitas bermain tujuh indera \\
\hline & & Tips memulai aktivitas bermain tujuh indera \\
\hline & & Pengembangan tema aktivitas bermain tujuh indera \\
\hline & & Rencana pelaksanaan aktivitas bermain tujuh indera \\
\hline
\end{tabular}


Pengembangan Media Stimulasi Sensori Anak Usia 4-6 Tahun Berbasis Aktivitas Bermain Tujuh Indera DOI: 10.31004/obsesi.v5i1.758

\begin{tabular}{ccc}
\hline $\begin{array}{c}\text { Struktur } \\
\text { Buku }\end{array}$ & $\begin{array}{c}\text { Bagian } \\
\text { Buku }\end{array}$ & \multicolumn{1}{c}{ Bahan dan Materi } \\
\hline & & Bentuk Aktivitas bermain tujuh indera \\
& $-\quad$ Tema Diri Sendiri/Tubuhku \\
& & $-\quad$ Tema Kebutuhanku/Makanan \& Minuman. \\
& & $-\quad$ Tema Lingkunganku/Rumahku \\
Lembaran & Penutup & Kata Penutup \\
\cline { 3 - 3 } Akhir & & Lembar evaluasi diri akhir \\
\cline { 3 - 3 } & & Daftar pustaka \\
\cline { 3 - 3 } & & Biografi Penulis \\
\hline Sampul & Sampul & Judul “Panduan stimulasi sensori anak usia 4-6 tahun berbasis \\
& Belakang & aktivitas bermain tujuh indera”. \\
\hline
\end{tabular}

Tabel 3 terfokus pada penulisan draft satu dengan kegiatan mengurutkan ide atau gagasan penulisan yang terurut dan sistematis sehingga mudah panduan dapat dipahami guru secara terstruktur. Ide penulisan panduan ini berdasarkan beberapa hambatan yang dialami guru dalam merancang aktivitas bermain yang dapat menstimulasi sensori pada anak karena pemahaman terkait sensori masih terbatas.

\section{Tabel 4 Pengembangan Aktivitas Bermain Tujuh Indera}

\begin{tabular}{|c|c|c|}
\hline Profil Indera & Nama Aktivitas Bermain & Tujuan Stimulasi Sensori \\
\hline $\begin{array}{c}\text { Indera } \\
\text { Penglihatan }\end{array}$ & $\begin{array}{l}\text { Bayangan Tubuh } \\
\text { Rangkai Makaroni } \\
\text { Gelap Terang Kamarku } \\
\text { Kejar Cahaya }\end{array}$ & $\begin{array}{l}\text { Melatih anak terbiasa terhadap cahaya sekitar, merespon } \\
\text { positif terhadap kegelapan, membangun fokus dan } \\
\text { konsentrasi kontak mata, mengasah persepsi visual anak, } \\
\text { melatih gerakan mata dan tangan secara terkoordinasi. }\end{array}$ \\
\hline $\begin{array}{c}\text { Indera } \\
\text { Pendengaran }\end{array}$ & $\begin{array}{l}\text { Tepuk Anggota Tubuh } \\
\text { Perkusi Bahan Makanan, } \\
\text { Bunyi peralatan rumah } \\
\text { dan suara sekitar }\end{array}$ & $\begin{array}{l}\text { Melatih anak mengidentifikasi bunyi dan suara yang di } \\
\text { dengar, melatih respon positif anak terhadap bunyi sekitar } \\
\text { baik keras atau pelan dan memperkaya pengalaman sensasi } \\
\text { bunyi sekitar. }\end{array}$ \\
\hline $\begin{array}{c}\text { Indera } \\
\text { Penciuman }\end{array}$ & $\begin{array}{lr}\text { Kotak mandi, } & \text { Aroma } \\
\text { makanan, } & \text { Harum } \\
\text { rumahku, Belanja Pasar. }\end{array}$ & $\begin{array}{l}\text { Melatih anak terbiasa dengan aroma yang kuat, } \\
\text { mengembangkan respon positif anak terhadap bau sekitar } \\
\text { dan memperkaya pengalaman indera penciuman anak } \\
\text { dengan aneka bau. }\end{array}$ \\
\hline $\begin{array}{c}\text { Indera } \\
\text { Pengecapan }\end{array}$ & $\begin{array}{l}\text { Oles Tipis, cicip kudapan, } \\
\text { colek bumbu dapur, cair } \\
\text { kental. }\end{array}$ & $\begin{array}{l}\text { Melatih anak terbiasa dengan berbagai rasa, mengasah } \\
\text { respon positif anak terhadap sensasi rasa, dan memperkaya } \\
\text { pengalaman sensasi rasa dari bahan sekitar. }\end{array}$ \\
\hline $\begin{array}{c}\text { Indera } \\
\text { Perabaan }\end{array}$ & $\begin{array}{lr}\text { Krim tubuh, } & \text { Sentuh } \\
\text { makanan, } & \text { Kreasi cat } \\
\text { rumahku, } & \text { Langkah } \\
\text { tekstur. }\end{array}$ & $\begin{array}{l}\text { Melatih anak terbiasa dengan berbagai macam tekstur } \\
\text { lembek dan kenyal, mengasah respon positif anak terhadap } \\
\text { berbagai tekstur, memperkaya pengalaman sensasi anak } \\
\text { terhadap aneka tekstur. }\end{array}$ \\
\hline $\begin{array}{c}\text { Indera } \\
\text { Vestibular }\end{array}$ & $\begin{array}{l}\text { Berjalan di atas garis, } \\
\text { Penyaji } \\
\text { berjalan diatas roda } \\
\text { bekas, berjalan diatas } \\
\text { dingklik. }\end{array}$ & $\begin{array}{l}\text { Mengontrol keseimbangan anak saat bergerak, melatih } \\
\text { respon positif anak terhadap perubahan posisi., melatih } \\
\text { gerakan tubuh anak secara terkoordinasi. }\end{array}$ \\
\hline $\begin{array}{c}\text { Indera } \\
\text { Proprioseptif }\end{array}$ & $\begin{array}{l}\text { Gerak pola kaki, Masak } \\
\text { bersama donatku, Tarik } \\
\text { selendang, Berjalan } \\
\text { traktor. }\end{array}$ & $\begin{array}{l}\text { Menguatkan otot tangan dan lengan, melatih anak } \\
\text { mengontrol kekuatan saat melakukan aktivitas., melatih } \\
\text { anak memegang dan menggunakan benda dan alat. }\end{array}$ \\
\hline
\end{tabular}

Tabel 5 menggambarkan hasil pengembangan aktivitas bermain tujuh indera yang sesuai dengan tahapan usia perkembangan anak dan mudah diterapkan oleh para guru dalam pembelajaran di lembaga pendidikan anak usia dini (Kranowitz, 2003; Schaaf et al., 2014). 
Penyajian aktivitas bermain tujuh indera berupa nama aktivitas, tujuan, dan media bermain yang dikemas dan terpadu dengan tema pembelajaran.

3) Kegiatan menyusun dan menulis serta menyunting panduan, sehingga panduan yang dikembangkan menjadi sebuah produk yang layak digunakan. Memulai draft awal buku, melengkapi dan sunting draft awal dengan sampul buku panduan serta mengembangkan instrumen berdasarkan tujuan objektif panduan stimulasi sensori anak usia 4-6 tahun berbasis aktivitas bermain tujuh indera. Setelah menyusun draft awal, peneliti melakukan uji kelayakan draft satu kepada para pakar sesuai dengan bidang keahlian yang sesuai dengan pengembangan buku panduan ini. Para pakar yang akan menguji terdiri dari pakar media, pakar medis, pakar psikologi, pakar pendidikan anak usia dini dan melakukan uji coba satusatu berdasarkan kualifikasi pendidikan dan uji coba kelompok kecil sekitar 15 orang guru TK yang bergabung dalam pusat kegiatan gugus organisasi Ikatan Guru Taman Kanak-Kanak lingkungan Kecamatan Cempaka Putih melalui grup whatsapp, google form dan video conference dikarenakan kondisi pandemi covid 19.

Dalam tahap implementasi peneliti melanjutkan kegiatan dengan menguji kelayakan draft kedua oleh para pakar dan uji coba lapangan utama yang bekerjasama dengan pihak Pusat Kegiatan Gugus Ikatan Guru Taman Kanak-Kanak dan Satuan Pelaksana Pendidikan Kecamatan Cempaka Putih, Jakarta Pusat untuk mendapat dukungan sumber daya manusia dalam mengimplementasikan produk ini di lapangan. Pelaksanaan uji coba tidak dapat dilakukan secara tatap muka langsung dikarenakan kondisi lingkungan dalam masa pendemi covid 19, maka dilakukan melalui kegiatan webinar video conference zoom meeting dan pengisian kuisioner pengguna buku panduan dengan menggunakan media google form. Hasil dari tahap implementasi ini peneliti melakukan perbaikan-perbaikan berdasarkan hasil uji kelayakan untuk menyempurnakan produk menjadi bentuk final.

Tahap evaluasi merupakan tahap akhir pengembangan ini melalui kegiatan mengevaluasi dari langkah-langkah yang telah dilakukan oleh peneliti. Dalam tahap evaluasi ini akan menghasilkan produk yaitu sebuah model final dan kelayakan model yang dikembangkan. Kegiatan evaluasi yang dilakukan peneliti dalam tahap ini adalah mengembangkan model final buku panduan stimulasi sensor dan aktivitas bermain tujuh indera serta mengolah hasil kelayakan secara teoritik berdasarkan validasi oleh para ahli dan kelayakan secara empiris berdasarkan kuisioner pengguna terkait dengan buku panduan ini. Populasi dalam penelitian ini adalah Para guru satuan pendidikan Taman Kanak-Kanak di Kota Administrasi Jakarta Pusat. Adapun teknik pengambilan sampel ynag dilakukan penelitian ini adalah teknik cluster sampling maka terpilih guru-guru Taman Kanak-Kanak Kecamatan Cempaka Putih Jakarta Pusat yang dijadikan sampel dengan pertimbangan para guru bersedia menerima segala pengembangan kompetensi guru yang berdampak pada peningkatan kompetensi pembelajaran yang diterapkan pada satuan pendidikan tempat tugas para guru.

Pengambilan sampel dilanjutkan dengan random sampling yang diambil para guru TK dari tiga kelurahan yang terdapat dalam Kecamatan Cempaka Putih. Penelitian ini menggunakan instrumen berupa instrumen kuisioner atau angket dengan kisi-kisi instrumen kebutuhan produk dan instrumen kelayakan produk yang telah dikonstruk oleh para pakar. Instrumen kebutuhan produk dalam tahap analisis kebutuhan menggunakan skala Guttman untuk mendapatkan jawaban "Ya" atau "Tidak" terkait pengetahuan dan keterampilan guru tentang stimulasi sensori dan aktivitas bermain indera dan jawaban "Ada" atau "Tidak Ada" terkait perilaku anak dengan masalah sensori yang muncul dalam aktivitas anak sehari-hari. Tahap analisis data yang digunakan untuk mengetahui kebutuhan produk dengan rumus sebagai berikut (Sugiyono, 2015):

$$
P(\text { Persentase })=\frac{f(\text { frekuensi Jawaban })}{n(\text { Jumlah Peserta })} \times 100 \%
$$


Instrumen kelayakan produk buku panduan stimulasi sensori menggunakan skala likert dengan analisis kuisioner berdasarkan kelayakan materi, teknik penyajian, relevansi dengan materi dan teknik bahasa. Pengumpulan data menggunakan kuisioner dalam bentuk google form yang dibagikan kepada para guru saat uji lapangan dan pertemuan melalui video conference. Google form dipilih dengan pertimbangan mudah, praktis dan waktu yang terjangkau. Data yang diperoleh dari instrumen kuesioner akan diubah ke dalam bentuk kualitatif dari hasil uji prosentase yang dihitung rata-rata jawaban dan dianalisa berdasarkan skoring perolehan tiap item. Berikut rumus persentasi kelayakan model sebagai berikut (Riduwan \& Sunarto, 2015):

$$
\% \text { Interpretasi }=\frac{\sum \text { Skor Perolehan }}{\sum \text { Skor Maksimal }} X 100 \%
$$

\section{HASIL DAN PEMBAHASAN}

Penelitian pengembangan produk buku panduan ini merupakan hasil dari tahapan dalam model pengembangan ADDIE yang terintegrasi model Rowentree yang telah di uji kelayakan oleh para pakar media dan pakar materi serta di uji cobakan kepada 35 orang guru TK untuk melihat kelayakan buku panduan. Nama produk final yang dikembangkan dalam penelitian ini adalah "Buku Panduan Stimulasi Sensori Anak Usia 4-6 Tahun Berbasis Aktivitas Bermain Tujuh Indera Bagi Guru" dengan sasaran buku ini adalah para guru yang mengajar anak usia 4-6 tahun. Berikut adalah karakteristik dari model final buku panduan stimulasi sensori sebagai berikut:

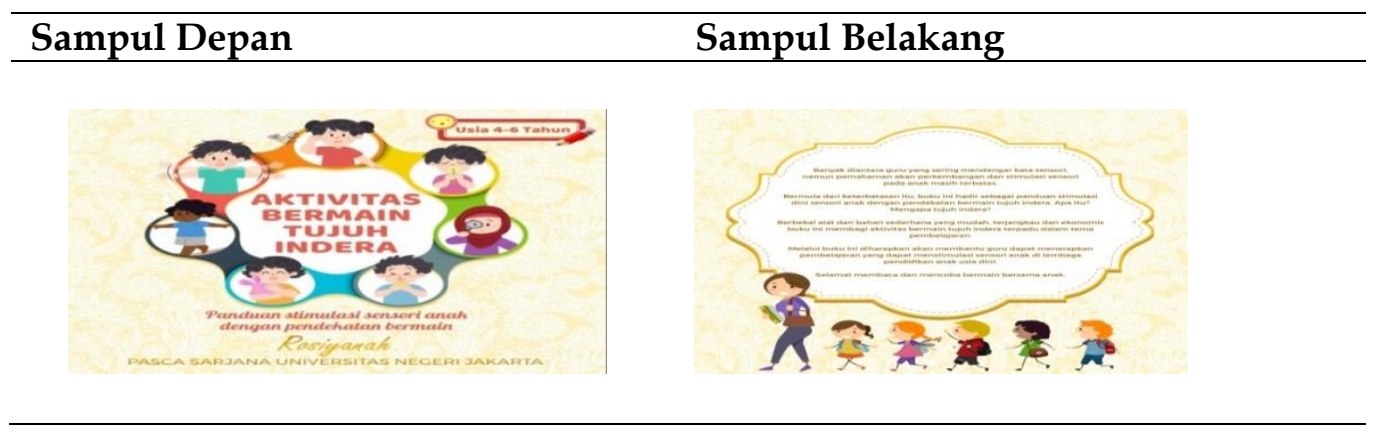

Gambar 1. Tampilan Sampul Buku Panduan

Pada gambar 1, bagian sampul depan disesuaikan dengan judul panduan yang menunjukkan kategori usia anak serta ilustrasi gambar yang mendukung isi konten buku panduan. Bagian sampul belakang berisi sinopsis materi buku panduan stimulasi sensori berbasis aktivitas bermain tujuh indera.

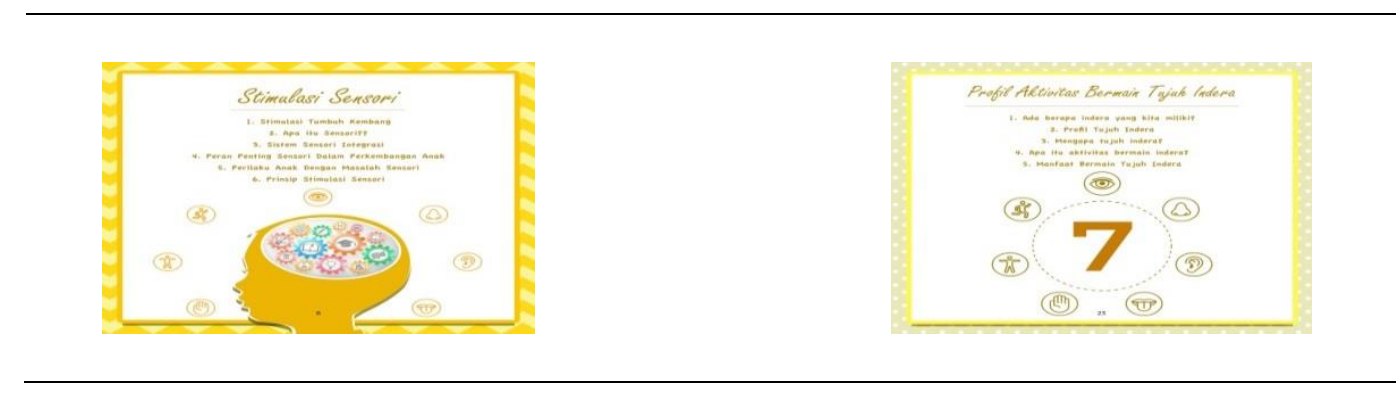

Gambar 2. Tampilan Sub Judul

Pada gambar 4, halaman ini berisi bagian sub judul yang terdapat pandangan umum mengenai sub bahasan dan uraian materi pada setiap bahasan sensori dan penerapan 
stimulasi sensori yang dilengkapi dengan pendapat para ahli, petunjuk dan tips pelaksanaan pembelajaran berbasis stimulasi sensori dengan pendekatan bermain.
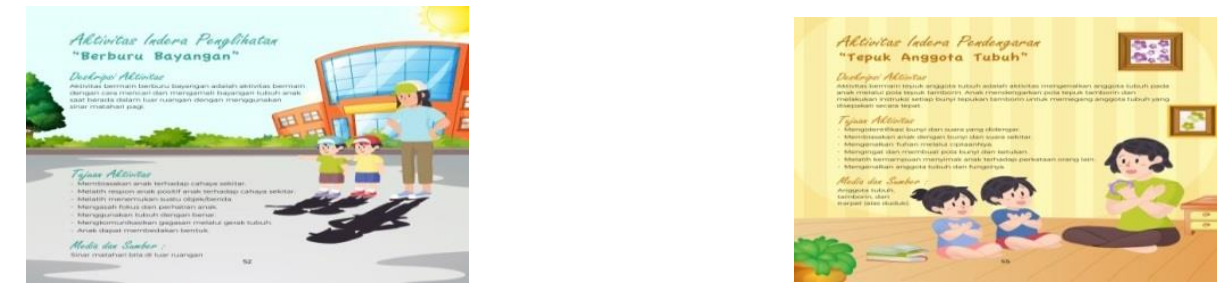

Gambar 3. Tampilan Aktivitas Bermain Tujuh Indera

Pada gambar 3, bagian ini berisi bentuk aktivitas bermain tujuh indera yang berisi nama aktivitas, deskripsi aktivitas, ilustrasi gambar aktivitas, tujuan dan media bermain yang dapat dengan mudah digunakan oleh para guru. Dalam aktivitas bermain ini dilengkapi dengan tahapan skenario bermain yang dapat memudahkan para guru menerapkan dalam pembelajaran. Selain itu pendukung aktivitas disertai asesmen perkembangan anak untuk mengevaluasi pencapaian perkembangan anak setelah dilaksanakan aktivitas bermain.

Uji kelayakan buku panduan stimulasi sensori anak usia 4-6 tahun berbasis aktivitas bermain tujuh indera dapat dibuktikan secara teoritik melalui validasi oleh para pakar. Peneliti menunjukkan instumen penilaian yang sesuai dengan bidang masing-masing. Para ahli mengisi instrumen dan memberikan sara perbaikan pengembangan buku panduan. Hasil pengisian angket dari para ahli / pakar kemudian dihitung jumlah skor yang diperoleh dibagi dengan jumlah skor maksimal kemudian dipersentasekan untuk melihat persentase kelayakan model. Dalam penelitian ini, para ahli materi yang telah mevalidasi adalah ahli medis, ahli psikologi, ahli PAUD, ahli praktisi sensori integrasi, dan ahli media sebagai para ahli dibidang yang berhubungan langsung dengan pengembangan buku panduan stimulasi sensori. Dari data hasil penilaian kelayakan buku panduan oleh para ahli tersebut diatas maka didapat data sebagai berikut:

Tabel 5 Hasil Kelayakan Teoritis

\begin{tabular}{lllll}
\hline No & Ahli & Persentase & Keterangan & Makna \\
\hline 1 & Ahli Media & $98,33 \%$ & Sangat Baik & Sangat Layak \\
\hline 2 & Ahli Medis & $94,95 \%$ & Sangat Baik & Sangat Layak \\
\hline 3 & Ahli PAUD & $93,37 \%$ & Sangat Baik & Sangat Layak \\
\hline 4 & Ahli Psikolog & $92,73 \%$ & Sangat Baik & Sangat Layak \\
\hline 5 & Ahli Praktisi SI & $94,37 \%$ & Sangat Baik & Sangat Layak \\
\hline
\end{tabular}

Pada tabel 5 menunjukkan hasil uji kelayakan oleh para pakar terkait pengembangan buku panduan stimulasi sensori anak usia 4-6 tahun berbasis aktivitas bermain tujuh indera sangat layak digunakan untuk meningkatkan kompetensi pedagogis, sikap dan profesional para pendidik anak usia 4-6 tahun di lingkungan Kecamatan Cempaka Putih Kota Jakarta Pusat Provinsi DKI Jakarta.

Uji kelayakan secara empiris dapat dibuktikan dari hasil penilaian yang diberikan oleh pengguna buku dalam penelitian ini adalah para guru lembaga pendidikan Taman KanakKanak di lingkungan Kecamatan Cempaka Putih. Aspek-aspek dalam instrumen penilaian adalah kelayakan materi, teknik penyajian, relevansi aktivitas bermain tujuh indera dengan stimulasi sensori, penyajian desain dan teknik bahasa. Semua ahli tersebut di atas juga telah melakukan validasi konstruk intrumen uji coba penggunaan buku panduan untuk guru pada penelitian ini. Setelah dinyatakan layak dan dilakukan revisi sesuai masukan para ahli, 
instrumen itu di uji cobakan setelah revisi instrumen menyatakan 25 butir pernyataan yang valid.

Uji kelayakan dilaksanakan sebanyak tiga kali yaitu uji coba one to one, uji coba kelompok kecil dan uji coba lapangan utama. Berikut adalah data hasil uji coba produk buku panduan sebagai berikut di bawah ini:

Tabel 6 Hasil Kelayakan Secara Empiris

\begin{tabular}{lllll}
\hline No & Jenis Uji Coba & Persentase & Keterangan & Makna \\
\hline 1 & Uji coba one to one & $75,52 \%$ & Baik & Layak \\
\hline 2 & Ujicoba kelompok kecil & $88,69 \%$ & Sangat Baik & Sangat Layak \\
\hline 3 & Uji coba Lapangan & $94,99 \%$ & Sangat Baik & Sangat Layak \\
\hline
\end{tabular}

Dari tabel 6 menunjukkan persentase peningkatan skor penilaian yang diberikan para pengguna buku panduan dalam setiap uji coba. Uji coba dilakukan untuk memastikan bahwa buku panduan yang dikembangkan telah sesuai dengan aspek-aspek dalam mengembangkan sebuah produk pembelajaran.

Hasil akhir dari tahap evaluasi berdasarkan hasil kelayakan secara teoritis yaitu kelayakan para ahli dan kelayakan secara empiris yaitu hasil uji coba penggunaan oleh para guru serta telah dilakukan revisi dari validator berdasarkan saran dan komentar yang bertujuan untuk perbaikan dari produk, sehingga pemakaian buku panduan dapat menjadi efektif dan komunikatif untuk para pengguna. Maka dapat disimpulkan bahwa produk buku panduan stimulasi sensori anak usia 4-6 tahun berbasis aktivitas bermain tujuh indera sangat layak digunakan secara umum dilihat dari beberapa aspek isi maupun tampilan buku, sehingga dapat menambah pengetahuan dan informasi serta meningkatkan kompetensi pedagogis, sikap dan profesional para pendidik dalam satuan pendidikan anak usia dini.

Penelitian ini menghasilkan buku panduan stimulasi sensori anak usia 4-6 tahun berbasis aktivitas bermain tujuh indera yang diperuntukkan untuk para guru pendidik anak usia dini sebagai hasil akhir penelitian. Pemberian stimulasi sensori selain dapat dilakukan oleh orang tua dan orang terdekat anak, dapat dilaksanakan oleh berbagai kalangan masyarakat, termasuk para guru dalam satuan pendidikan anak usia dini. Salah satu dasar dalam mengembangkan buku panduan stimulasi sensori ini adalah perilaku anak dengan masalah sensori yang sering kali muncul dalam pembelajaran dan kurang dipahami oleh para guru, sehingga menjadi hambatan dalam aktivitas anak sehari-hari. Berangkat dari kondisi ini dibutuhkan sebuah panduan stimulasi sensori yang dapat disosialisasikan melalui pelatihan guru dengan menggunakan bahan ajar yang tepat, memungkinkan para guru dapat mengintegrasikan program stimulasi sensori ke dalam proses pembelajaran (Pribadi, 2015). Buku panduan stimulasi sensori ini akan membantu guru dalam memberikan stimulasi yang tepat dan sesuai dengan tingkat pencapaian perkembangan anak dengan memperhatikan beberapa prinsip dalam penerapan pemberian stimulasi. Prinsip stimulasi sensori mengacu pada antara hubungan sensasi dengan gerakan, dimana pesan sensorik datang dari tubuh dan dunia sekitar melalui kegiatan yang sesuai dengan tahapan, menyenangkan dan mudah dilakukan anak dan efisien secara ekonomis, sehingga dapat diterapkan guru dalam aktivitas pembelajaran harian (Gunadi, 2015; Kranowitz, 2003; Setyowati, 2019). Pengalaman sensori dapat diberikan melalui pendekatan bermain yang menyenangkan melalui kegiatan bermain berbasis inderawi sebagai salah satu alternatif kegiatan bermain yang secara aktif melibatkan lebih dari satu indera.

Materi utama dalam buku panduan ini terletak pada pengembangan aktivitas bermain tujuh indera merupakan suatu proses bermain yang melibatkan tujuh indera secara aktif sebagai media stimulasi kemampuan sensori pada anak usia dini. Proses kerjasama antar tujuh indera ini dapat memudahkan anak memahami apa yang terjadi di lingkungan dan membantu anak berinteraksi dengan baik. Melalui terintegrasi ketujuh indera tersebut diatas 
manusia mengumpulkan informasi yang diterima dan menentukan respon yang tepat terhadap suatu situasi tertentu( Nissan, Yochman, Blumer, Kharouba, \& Peretz, 2017). Ketujuh sistem indera memegang peranan penting dalam penerimaan dan proses sensori sehingga anak dapat memberikan respon yang tepat terhadap sensasi yang ada disekitar mereka. Pada kenyataan para orangtua, pendidik dan pengasuh anak umumnya terbiasa dengan pemahaman lima indera yaitu penglihatan, pendengaran, penciuman, sentuhan dan rasa. Banyak yang mungkin tidak meyadari bahwa ada dua indera tambahan yaitu indera vestibular dan indera proprioseptif yang sering dikenal dalam teori sensori integrasi.

Aktivitas bermain tujuh indera yang dirancang dalam buku panduan untuk memudahkan guru dalam menstimulasi sensori dengan menggunakan pendekatan bermain yang dapat memperkaya pengalaman sensori anak, sehingga anak dapat menerima, mengolah dan merespon dengan wajar setiap sensasi yang muncul di sekitar anak. Montessori mengatakan bahwa pengalaman sensori lebih diutamakan daripada tuntutan secara akademik bagi anak usia dini. Permainan indera dapat mengaktifkan sensori yang memiliki fungsi dalam meningkatkan pembelajaran, membangun ketrampilan kognitif dan menyelesaikan konflik sosial emosional anak (Bracegirdle, 2015). Melalui permainan indera dapat menstimulasi sensori yang menumbuhkan ekspresi kreatif dan membangun kepercayaan diri dan harga diri anak. Melalui aktivitas bermain tujuh indera yang melatih anak untuk terbiasa memberikan respon positif dan tepat setiap informasi sensori yang diterima anak. Pendekatan bermain dinilai efektif untuk menstimulasi sensori untuk kematangan kemampuan sensori yang dapat memudahkan anak beraktivitas sehari-hari.

Pengembangan buku panduan stimulasi sensori ini sudah melalui tahapan validasi untuk menguji tingkat kelayakan produk. Validasi dilakukan oleh validator yang ahli materi dengan metode angket mendapat persentase $94,30 \%$ yang dikategorikan sangat layak, sedangkan validasi yang dilakukan oleh ahli media diperoleh 98,33\% yang dikategorikan sangat layak. Hasil dari pengembangan produk berupa buku panduan yang telah dilakukan revisi dari validator ahli berdasarkan saran dan masukan guna perbaikan dari produk, sehingga dalam penggunaan buku panduan akan menjadi lebih efektif dan efisien serta mudah dipahami bagi para pengguna produk. Dari hasil validasi dari para ahli makan dapat disimpulkan bahwa buku panduan stimulasi sensori pada anak usia 4-6 tahun berbasis aktivitas bermain tujuh indera adalah sangat layak di uji cobakan ke lapangan utama, yakni para guru anak usia dini untuk melihat apakah buku panduan layak digunakan. Hasil uji coba lapangan utama di Kecamatan Cempaka Putih Jakarta Pusat dengan menggunakan angket yang disebarkan melalui google form mendapatkan persentase 94, 99\% maka dapat di tarik kesimpulan bahwa buku panduan stimulasi sensori pada anak usia 4-6 tahun berbasis aktivitas bermain tujuh indera dikategorikan sangat layak untuk digunakan oleh para guru anak usia dini sebagai acuan atau referensi dalam menstimulasi sensori melalui aktivitas bermain tujuh indera yang telah terkonsep dan sistematis.

Keberhasilan dari produk buku panduan ini sejalan dengan penelitian yang menyatakan bahwa setelah guru mendapatkan sosialisasi membaca buku perkembangan sensori maka guru dapat merancang lingkungan belajar yang memperkaya pengalaman sensori anak (Nel, Joubert, \& Hartell, 2017). Hal ini membuktikan bahwa guru juga membutuhkan pembinaan terkait dengan pengetahuan dan keterampilan stimulasi sensori dengan pendekatan bermain agar para guru anak usia dini dapat merencanakan, melaksanakan dan melakukan penilaian pembelajaran berbasis stimulasi sensori dengan tepat sehingga dapat mengoptimalkan perkembangan anak. Adanya perubahan dari kompetensi pedagogis, sikap dan profesional guru menjadi tujuan dalam pengembangan buku panduan ini akan memberikan dampak yang positif terhadap komunikasi dan interaksi antara guru dan anak sehingga dapat mengembangkan pembelajaran yang dapat mengoptimalkan kematangan dan kesiapan anak belajar anak secara akademik saat anak memasuki sekolah dasar. 


\section{SIMPULAN}

Pengembangan buku panduan ini secara prosedural melalui tahapan dan langkah pengembangan dengan serangkaian uji kelayakan para ahli dan uji coba lapangan serta proses revisi sampai dihasilkan model final sebagai bentuk akhir produk maka buku panduan stimulasi sensori anak usia 4-6 tahun berbasis aktivitas bermain tujuh indera telah menunjukkan kelayakan sebagai referensi para guru untuk memiliki pengetahuan dan pemahaman tahapan perkembangan dan stimulasi sensori, memiliki rasa tanggung jawab yang tinggi dengan mendukung program pemberian stimulasi sensori, dan memiliki kemampuan dalam memberikan ransangan pendidikan dan merancang, melaksanakan serta menilai aktivitas bermain yang dapat menstimulasi sensori terintegrasi dalam kegiatan belajar anak di lembaga pendidikan masing-masing. Sehingga tindak lanjut hasil produk buku panduan ini dapat diimplementasikan oleh guru, maka sangat penting disosialisasikan dalam sebuah bentuk pelatihan yang bertujuan untuk meningkatkan keterampilan guru dalam melakukan tata laksana pembelajaran berbasis stimulasi sensori dengan pendekatan bermain.

\section{UCAPAN TERIMA KASIH}

Ucapan terima kasih kepada para kepala sekolah, guru dan lembaga Taman KanakKanak Kecamatan Cempaka Putih Jakarta Pusat atas dukungan dan bantuan atas terselesaikannya artikel ilmiah ini.

\section{DAFTAR PUSTAKA}

Andriani, D. (2017). Kiat Menghadapi Anak dengan Gangguan Sensori. Tempo. Retrieved from https:/ / cantik.tempo.co/read/ 858285/ kiat-menghadapi-anak-dengan-gangguansensori $/$ full\&view $=$ ok

Bagby, M. S., Dickie, V. A., \& Baranek, G. T. (2012). How Sensory Experiences of Children With and Without Autism Affect Family Occupation. Journal National Institutes Of Health, 66, 78-86. https:// doi.org/10.1016/j.jacc.2007.01.076.White

Benson, J. D., Breisinger, E., \& Roach, M. (2019). Sensory-based intervention in the schools: a survey of occupational therapy practitioners. Journal of Occupational Therapy, Schools, and Early Intervention, 12(1), 115-128. https:/ / doi.org/10.1080/19411243.2018.1496872

Bracegirdle, H. (2015). The Use of Play in Occupational Therapy for Children: Normal Play Development. British Journal of Occupational Therapy, 55(4), 141-142. https://doi.org/10.1177/030802269205500405

Butcher, K., \& Pletcher, J. (2016). Cognitive development and sensory play. Michigan State University Extension. Retrieved from https://www.canr.msu.edu/news/cognitive_development_and_sensory_play

Chuang, T. Y., Kuo, M. S., Fan, P. L., \& Hsu, Y. W. (2017). A kinect-based motion-sensing game therapy to foster the learning of children with sensory integration dysfunction. Educational Technology Research and Development, 65(3), 699-717. https://doi.org/10.1007/s11423-016-9505-y

Coulthard, H., Williamson, I., Palfreyman, Z., \& Lyttle, S. (2018). Evaluation of a pilot sensory play intervention to increase fruit acceptance in preschool children. Appetite, 120, 609_ 615. https:// doi.org/10.1016/j.appet.2017.10.011

Critz, C., Blake, K., \& Nogueira, E. (2015). Sensory Processing Challenges in Children. Journal for Nurse Practitioners, 11(7), 710-716. https:/ / doi.org/10.1016/j.nurpra.2015.04.016

Dunn, W. (1999). Sensory Profile.pdf.

Edwards, J. (2017). The importance of sensory play in children and how to encourage it. Retrieved from https://profilemag.com.au/the-importance-of-sensory-play-inchildren-and-how-to-encourage-it/

Fina, F. J. . (2016). Hubungan stimulasi dini sensoris dengan perkembangan motorik anak usia 2-3 tahun. IOSR Journal of Economics and Finance, 3(1), 56. 
https:// doi.org/https:// doi.org/10.3929/ethz-b-000238666

Gladstone, M., Douglas, G., Chimoyo, J., Jolley, E., Lynch, P., McLinden, M., \& Schmidt, E. (2018). 'I have learnt to love the child and give opportunities to play with peers': A feasibility study of the training programme to support parents of young children with visual impairment in Malawi. Journal of Early Childhood Research, 16(2), 210-225. https:// doi.org/10.1177/1476718x18761219

Grantham-Mcgregor, S., \& Smith, J. A. (2016). Journal of Applied Research on Children: Informing Policy for Children at Risk Extending The Jamaican Early Childhood Development Intervention. Journal of Applied Research on Children: Informing Policy for Children at Risk, 7(2). Retrieved from http://digitalcommons.library.tmc.edu/childrenatrisk\%0Ahttp:/ / digitalcommons.li brary.tmc.edu/childrenatrisk/vol7/iss2/4

Gunadi, T. (2015). Sensory Integration in Austism. (Empat, Ed.) (Empat). Jakarta: College Allied Educator Indonesia.

Hastuti, L. S., \& Kurnia, R. (2016). Hubungan Sensory Profile dengan Kemandirian Aktifitas Fungsional dan Prestasi Akademik Anak Sekolah Dasar kelas Satu Di Desa Sawahan, Ngemplak, Boyolali. Interest: Jurnal Ilmu Kesehatan, 5(2).

Johnson, N., Pushko, K., Stanley, B., Taylor, J., Taylor, J., Considine, B., ... Div, M. (2018). Babies Count.

Khowaja, H. A. (2017). What Stimulation That Parents Can Provide to Their Child for His/ Her Holistik Development From The Time of Conception Till.

Kranowitz, C. S. (2003). The out of Sync has fun; activities for kids with sensory integration dysfucntion. Newyork: The Berkley Publishing Group.

Nel, A., Joubert, I., \& Hartell, C. (2017). Teachers' perceptions on the design and use of an outdoor learning environment for sensory and motor stimulation. South African Journal of Childhood Education, 7(1), 11. https://doi.org/10.4102/sajce.v7i1.482

Nesayan, A., Asadi Gandomani, R., Movallali, G., \& Dunn, W. (2018). The relationship between sensory processing patterns and behavioral patterns in children. Journal of Occupational Therapy, Schools, and Early Intervention, 11(2), 124-132. https:// doi.org/10.1080/19411243.2018.1432447

Nissan, S., Yochman, A., Blumer, S., Kharouba, J., \& Peretz, B. (2017). Children's responses to sensory stimuli and their behavior in the dental office. Journal of Clinical Pediatric Dentistry, 41(1), 10-17. https:/ / doi.org/10.17796/1053-4628-41.1.10

Par, Y., Pike, A., \& Ayers, S. (2014). Infant Developmental Outcomes: A Family Systems Perspective, 373(November 2013), 353-373. https:/ / doi.org/10.1002/icd

Prawadilaga, D. S. (2015). Prinsip desain pembelajaran, Instructional Design Principles (kelima). Prenadamedia Group.

Pribadi, B. R. (2015). Desain dan Pengembangan Program Pelatihan Berbasis Kompetensi (Kedua). Jakarta: Prenadamedia Group.

Riduwan, \& Sunarto. (2015). Pengantar Statistika Pendidikan, Sosial, Ekonomi, Komunikasi dan Bisnis. (Akdon, Ed.) (Delapan). Bandung: Alfabeta.

Rowentree, D. (1994). Preparing Materials for Open Dsitance and Flexible Learning, An Action Guide for Teachers and Trainers. (First). Kogan Page.

Schaaf, R. C., Dumont, R. L., Arbesman, M., \& May-Benson, T. A. (2017). Efficacy of Occupational Therapy Using Ayres Sensory Integration ${ }^{\circledR}$ : A Systematic Review. American Journal of Occupational Therapy, 72(1), 7201190010p1. https:// doi.org/10.5014/ajot.2018.028431

Schaaf, R. C., Mailloux, Z., Burke, J. P., Cohn, E., May-Benson, T. A., Schoen, S. A., ... Parham, L. D. (2014). State of measurement in occupational therapy using sensory integration. American Journal of Occupational Therapy, 68(5), e149-e153. https:// doi.org/10.5014/ajot.2014.012526

Setyosari, P. (2013). Metode penelitian pendidikan dan Pengembangan. Prenadamedia Group. 
DOI: 10.31004/obsesi.v5i1.758

Setyowati, R. B. (2019). Perkembangan sensomotorik. Jakarta: Cipta Aliansi Edukasi.

Sugiyono. (2015). Metode Penelitian Kuantitatiff, Kualitatif Dan RED (keempat). Bandung: PT Alfabeta.

Thompson, S. D., \& Rains, K. W. (2009). Learning About Sensory Integration Dysfunction: Strategies to Meet Young Children's Sensory Needs at Home. Young Exceptional Children, 12(2), 16-26. https:/ / doi.org/10.1177/1096250608328242

Wan Yunus, F., Liu, K. P. Y., Bissett, M., \& Penkala, S. (2015). Sensory-Based Intervention for Children with Behavioral Problems: A Systematic Review. Journal of Autism and Developmental Disorders, 45(11), 3565-3579. https://doi.org/10.1007/s10803-015-25039

Watts, T., Stagnitt, K., \& Brown, T. (2014). Relationship between play and sensory processing: A systematic review. American Journal of Occupational Therapy, 68(2), e37-e46. https://doi.org/10.5014/ajot.2014.009787

Watts, T., Stagnitti, K., \& Brown, T. (2014). Relationship between play and sensory processing: A systematic review. American Journal of Occupational Therapy, 68(2), e37-e46. https://doi.org/10.5014/ajot.2014.009787

Welters-Davis, M., \& Lawson, L. M. (2011). The relationship between sensory processing and parent-child play preferences. Journal of Occupational Therapy, Schools, and Early Intervention, 4(2), 108-120. https:/ / doi.org/10.1080/19411243.2011.595300

Yaswinda, Yulsyofriend, \& Mayar, F. (2018). Pengembangan Bahan Pembelajaran Sains Berbasis Multisensori Ekologi Bagi Guru PAUD Kecamatan Tilatang Kamang Kabupaten Agam. Pendidikan Anak Usia Dini, II(1).

Yudhiatmoko, A. (2014). Validation and Reliability Study of Short Sensory Profile (SSP) Instrument for Children age 3-10 years.

Zipp, G. P., \& Olson, V. (2016). Use Of Train-The-Trainer Sensorimotor Group Experience (TTSMGE) To Promote Functional Motor Skill Development In An Urban US Preschool Environment. Contemporary Issues in Education Research (CIER), 3(1), 83. https://doi.org/10.19030/cier.v3i1.165 